\title{
Comentário IX
}

\section{Historicizando as representações do passado}

\author{
José Reginaldo Santos Gonçalves ${ }^{1}$ \\ Man learns the concept of the past by remembering. \\ Ludwig Wittgenstein
}

Ao historicizar as representações do passado, o autor presta um serviço relevante ao dirigir a atenção de seus leitores para a natureza precária e instável dessas representações, sejam elas produzidas no mundo acadêmico, sejam produzidas e utilizadas na sociedade mais ampla. Assim, problematiza simultaneamente a história como conhecimento acadêmico e os usos do passado pelas sociedades contemporâneas.

Expressando um significativo (e talvez já estabilizado) deslocamento intelectual na comunidade de historiadores lassim como na comunidade dos antropólogos e nas ciências humanas em geral), no sentido de elaborar uma auto-reflexão sobre suas respectivas práticas disciplinares, o autor focaliza, de modo elegante, diversas modalidades por meio das quais o passado vem a ser representado, seja na forma escrita seja na forma visual.

$\bigcirc$ ponto forte na sua argumentação está no reconhecimento de que o passado, embora exista independentemente dos seus intérpretes, somente assume existência significativa por meio do trabalho interpretativo.

$\bigcirc$ passado, para o autor, deixa de ser considerado como um dado natural, na medida em que ele enfatiza o incontornável trabalho de reconstrução a que deve ser submetido (por diversos tipos de historiadores), cujo produto pode assumir, entre outras, as formas de "tradição" ou de "história".

Em outras palavras, o autor sublinha a necessidade de romper com o pressuposto ingênuo de que "a existência pura e simples das experiências passadas é a garantia segura para a história como disciplina".

1. Professor Associado de Antropologia Cultural do Programa de Pós-graduação em Sociologia e Antropologia do Instituto de Filosofia e Ciências Sociais , Universidade Federal do Rio de Janeiro; Pesquisador do CNPq. E-mail: $<$ reginald@ifcs.ufrj.br>. 
Evidentemente, nem todos na comunidade dos historiadores hão de concordar com esses argumentos, considerando-se o quanto a identidade desses profissionais está fortemente ancorada no paciente trabalho de pesquisa de arquivos, colocando-se usualmente em segundo plano (quando não simplemente condenando) todo e qualquer esforço de auto-reflexão.

Mas talvez o ponto focal do texto esteja no tratamento da questão das relações entre o invisível e o visível, ou como, de formas diversas, os historiadores transformam o primeiro no segundo.

Baseando-se em algumas reflexões pertinentes de Ulpiano Bezerra de Meneses, o autor vem problematizar as apropriações das imagens do passado em termos estritamente documentais, sendo essas usadas como "fontes", "tradição que acabou por encontrar uma larga aceitação entre os historiadores, sobretudo a partir do século XX".

Focalizando os mecanismos por meio dos quais veio a ser legitimada a moderna história enquanto disciplina científica, o autor focaliza a experiência dos antiquários, para os quais o passado mantém uma relação de continuidade com o presente, sendo suas imagens, seus objetos materiais, seus rastros concebidos como formas de manifestação sensível daquele.

O antiquário veio a ser concebido como uma espécie de "outro" para o historiador científico. Contra o primeiro, este concebe o passado como um domínio distante e cujo conhecimento possa de algum modo ser útil ao presente, demarcando assim uma fronteira que supostamente o separaria do saber "précientífico" do antiquário, caracterizado como sem finalidade e como uma forma de conhecimento reduzida à erudição.

Para a história concebida como projeto científico no século XIX, um projeto de futuro informa a representação do passado, o que vem desencadear a derrota da erudição (fortemente associada aos antiquários) e a conseqüente transformação do passado em "história".

Enfatizando a inseparabilidade entre o conhecer e o imaginar, o autor problematiza o caráter dado ou naturalizado dessas fronteiras que foram historicamente construídas entre a história como projeto científico e o conhecimento antiquário.

Essa problematização do conhecimento histórico em suas diversas modalidades pode, segundo o autor, afetar o trabalho de percepção e escrita de nosso presente. Nesse sentido, penso que não será inoportuno lembrar a vigência continuada das demais formas de conhecimento histórico - como, por exemplo, aquela representada pelo modelo do antiquário. Essas formas, longe de terem desaparecido, na verdade persistem em diversos domínios sociais e institucionais, resistentes aos esforços de problematização e, ironicamente, denunciando o caráter ilusório das visões teleológicas que possamos assumir sobre esse conhecimento.

Desse modo, não é que hoje estejamos livres de formas de conhecimento do passado supostamente superadas; não é que, tendo historicizado essas formas, estejamos definitivamente curados de seu apelo; não podemos dizer que hoje sabemos "mais" sobre o passado ou que nosso 
conhecimento seja mais verdadeiro; na verdade, o máximo que podemos dizer é que dispomos hoje de um leque mais amplo de metáforas por meio das quais representar o passado, diversas constelações de metáforas norteadas por distintos "regimes de historicidade".

Um dos efeitos, e não o menos importante, dessa atitude de auto-reflexão (atitude expressa com simplicidade e erudição pelo autor) sobre nossas práticas disciplinares (seja a do historiador, seja a do antropólogo cultural) consiste em percebermos de forma mais tolerante, porque sempre incontornavelmente contingentes, os conhecimentos produzidos sobre o passado, as difusas representações sociais sobre o transcurso do tempo, e que ancoram sensivelmente as estratégias de produção de subjetividades individuais e coletivas.

$\bigcirc$ passado - seja ele submetido às atuais e obsessivas formas de visualização representadas pelo chamado "patrimônio" seja ele representado na escrita dos historiadores - é, na verdade, concebido nas reflexões do autor não como uma entidade distante e reificada, mas como o efeito de uma atividade presente e contingente, submetida a regras que variam no tempo e no espaço. Afinal, é somente no esforço presente de construir o passado que aprendemos a usar essa categoria.

Assim, em termos de representação do passado, mesmo diante do que o autor chama de uma "nova forma experiência sensorial permitida pelos meios eletrônicos e virtuais", é preciso resistir ao enfeitiçamento que esses últimos possam eventualmente desencadear. Uma forma terapêutica de fazê-lo é, talvez, reconhecer a vigência contemporânea, efetiva e mutuamente desafiadora, de múltiplos "regimes de historicidade", interrompendo desse modo o impulso poderoso no sentido de impor a esse cenário quaisquer formas de representação linear e teleológica do tempo.

Apoiando-se em Italo Calvino, o autor conclui que a única "certeza que nos é possível [é a de que] pensar sobre o passado, imaginá-lo, e por isso poder conhecê-lo, trazendo à visão o invisível, comportou inúmeras possibilidades com diferentes formas".

É preciso sublinhar, no entanto, que algumas dessas formas de conhecimento do passado podem surpreender e frustrar nossas expectativas de vê-las estavelmente aprisionadas em alguma distante conjuntura histórica. Elas podem, na verdade, manifestar-se no presente, em um tempo que, não sendo um tempo "homogêneo e vazio", configura-se, na poderosa sugestão de Walter Benjamin, como "um tempo saturado de 'agoras' Uetztzeit)". 